\title{
PENJUALAN KREDIT SUKU CADANG BEARING BERBASIS VB.NET PADA CV ACE JAYA ABADI
}

\author{
Yeny Rostiani' ${ }^{1}$, Hasmizal ${ }^{2}$, Donny Apdian ${ }^{3}$, Susan Tresnawulan ${ }^{4}$ \\ 1,2,3,4STMIK Rosma Karawang \\ e-mail: yeny@rosma.ac.id, hasmizal@dosen.rosma.ac.id, donny@dosen.rosma.ac.id, \\ susan.tresna@mhs.rosma.ac.id
}

\begin{abstract}
Abstrak
CV Ace Jaya Abadi merupakan salah satu perusahaan dagang yang bergerak dibidang penjualan yang merupakan perusahaan berbasis bisnis dibidang pabrikan, agensi dan perorangan. Untuk mengelola penjualannya diperlukan suatu penanganan sistem akuntansi yang baik. Penulis membahas bagaimana penerapan komputerisasi akuntansi penjualan kredit suku cadang jenis bearing pada CV Ace Jaya Abadi. Metodologi yang digunakan dalam penelitian ini meliputi Analisa Sistem, Perancangan Sistem, dan Implementasi Sistem. Analisa Sistem dalam bahasa, hal ini meliputi Analisa Sistem yang Berjalan dan Analisa Masalah serta Solusi. Perancangan Sistem meliputi Perancangan Masukan, Keluaran, Proses dan Database. Sedangkan Metode Implementasi Sistem meliputi penyusunan program dan tes program. Dalam menyelenggarakan prosedur yang berjalan, CV Ace Jaya Abadi saat ini dalam pengolahan datanya terutama pada proses penanganan order dari pelanggan menggunakan microsoft excell dan kemudian transaksi tersebut dicatat kembali ke buku besar penjualan secara manual, dengan maksud menghindari apabila terjadi kerusakan pada komputer. Sehingga membutuhkan waktu lama dalam penanganan order, dan pencarian informasi data laporan penjualan tidak bisa dilakukan secara cepat. Dengan penerapan sistem penjualan diharapkan akan dapat bermanfaat bagi perusahaan dalam pembuatan laporan penjualan kredit maupun penangan order yang lebih mudah dimasa yang akan datang.
\end{abstract}

Kata Kunci : Penjualan, Kredit, Utang, Sistem, Vb.Net

\begin{abstract}
CV Ace Jaya Abadi is a trading company engaged in sales which is a business-based company in the field of manufacturing, agencies and individuals. To manage sales, a good accounting system is needed. The author discusses how to apply computerized accounting for credit sales of bearing spare parts at CV Ace Jaya Abadi. The methodology used in this research includes System Analysis, System Design, and System Implementation. System Analysis in language, this includes Analysis of Current Systems and Analysis of Problems and Solutions. System Design includes Input, Output, Process and Database Design. While the System Implementation Method includes the preparation of programs and program tests. In carrying out ongoing procedures, CV Ace Jaya Abadi is currently processing its data, especially in the process of handling orders from customers using Microsoft Excel and then the transaction is recorded back into the sales ledger manually, with the intention of avoiding any damage to the computer. So it takes a long time in handling orders, and searching for sales report data information cannot be done quickly. With the implementation of the sales system, it is hoped that it will be useful for companies in making credit sales reports and easier order handling in the future..
\end{abstract}

Keywords: Sales, Credit, Debt, System, Vb.Net 


\section{Pendahuluan}

Kemajuan teknologi dan komunikasi saat ini terus mengalami perkembangan yang sangat pesat. Informasi yang tepat dan akurat menjadi bagian yang sangat penting dalam menjalankan usaha atau bisnisnya(Yusuf, 2019). Informasi akan cepat didapat apabila didukung dengan sumber daya manusia yang berkualitas yang mampu memanfaatkan dibidang informasi. Kemajuan teknologi dapat diterapkan dalam setiap bidang yang ada pada saat ini, salah satunya adalah pada bidang penjualan. Penjualan merupakan salah satu aspek yang penting dalam sebuah perusahaan untuk memperoleh keuntungan(Permana \& Romadlon, 2019). Sehingga perusahaan harus dapat meningkatkan jumlah konsumen dan harus mampu bersaing secara ketat dengan beberapa perusahaan yang bergerak dibidang penjualan, terutama penjualan suku cadang jenis bearing.

Penjualan terdiri dari dua macam yaitu penjualan secara tunai dan kredit. Dalam penjualan secara kredit suatu perusahaan tentu membutuhkan sistem yang baik, yang kemudian dapat menghasilkan laporan yang baik pula dalam penanganan order maupun laporan penjualan(Sitorus \& Kurniawan, 2021).

CV Ace Jaya Abadi merupakan perusahaan yang berdiri sejak tahun 2008, perusahaan ini bergerak dibidang penjualan suku cadang untuk kendaraan dan mesinmesin perusahaan yaitu bearing. Namun saat ini dalam pengolahan datanya terutama pada proses penanganan order dari pelanggan menggunakan microsoft excell dan kemudian transaksi tersebut dicatat kembali ke buku besar penjualan secara manual, dengan maksud menghindari apabila terjadi kerusakan pada komputer. Sehingga membutuhkan waktu lama dalam penanganan order, dan pencarian informasi data laporan penjualan tidak bisa dilakukan secara cepat.

Berdasarkan permasalahan tersebut, perlu kiranya dirancang sistem yang terkomputerisasi dan terintegrasi dengan database sehingga penjualan kredit dapat dilakukan dengan cepat dan menghasilkan laporan yang akurat. Maka dari itu penulis tertarik untuk membuat rancangan program dengan menggunakan Microsoft Visual Studio.net 2008 dan SQL Server 2005 sebagai database nya

\section{Metode Penelitian}

Metode penelitian yang penulis gunakan dalam merancang aplikasi pada penelitian ini menggunakan SDLC (System Development Life Cycle) dengan model waterfall(Sadiah, Indaryono, \& Yusuf, 2021). Model waterfall menyediakan pendekatan alur hidup perangkat lunak secara sekuensial atau terurut dimulai dari analisis kebutuhan sistem, desain, pengkodean, pengujan, dan tahap pendukung(Rosa A.S, 2016). Berikut ilustrasi model waterfall dengan langkah-langkahnya :

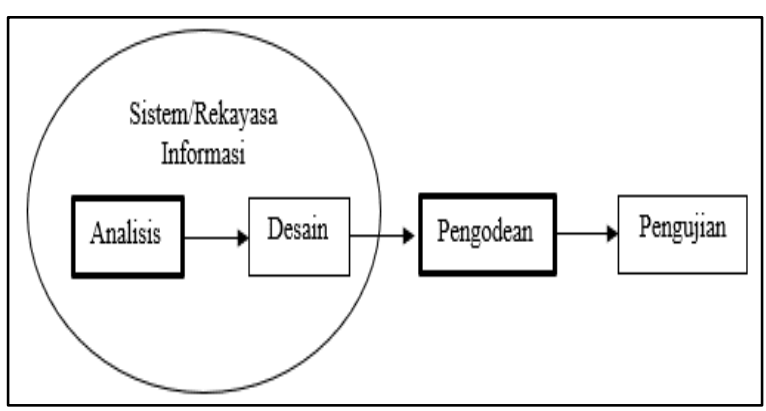

Gambar 1. Tahapan Waterfall

Sumber : (Rosa A.S, 2016)

a. Analisis Kebutuhan Perangkat Lunak Proses pengumpulan kebutuhan dilakukan secara intensif untuk menspesifikasikan kebutuhan perangkat lunak agar dapat dipahami perangkat lunak seperti apa yang dibutuhkan oleh user(Hendrawan, 2019).

Penelitian yang dilakukan penulis diantaranya :

$>$ Observasi

Pengumpulan data yang dilakukan dengan cara pengamatan langsung terhadap objek yang akan diteliti dan bagian terkait(Arsyad, Kurnia, \& Kartika, 2021).

$>$ Wawancara

Teknik pengumpulan data dengan cara komunikasi Tanya jawab untuk mendapatkan informasi dan tanggapan secara langsung kepada suatu pihak yang terkait(Bastian, Winardi, \& Fatmawati, 2018). Proses pengumpulan data, keterangan, dan bahan-bahan yang diperlukan dalam penelitian.

$>$ Studi Pustaka

Teknik pengumpulan data di perpustakaan dengan mengumpulkan atau menggunakan sumber-sumber tertulis yang 
bersumber pada buku-buku dan dokumen-dokumen yang berkaitan dengan masalah yang diteliti sebagai landasan teori(Sugiyono,

b. Desain 2019).

Desain perangkat lunak adalah proses multi langkah yang fokus pada desain pembuatan program perangkat lunak termasuk struktur data, arsitektur perangkat lunak, representasi antarmuka, dan prosedur pengodean(Febrianto, 2020). Tahap ini mentranslasi kebutuhan perangkat lunak dari tahap analisis kebutuhan ke representasi desain agar dapat diimplementasikan menjadi program pada tahap selanjutnya.

c. Pembuatan Kode Program

Tahap ini desain harus ditranslasikan ke dalam program perangkat lunak(Febrianto, 2020). Hasil dari tahap ini adalah program komputer sesuai dengan desain yang telah dibuat pada tahap desain. Dalam merancang program penulis menggunakan bahasa pemrograman VB .Net.

d. Pengujian

Pengujian fokus pada perangkat lunak secara dari segi lojik dan fungsional dan memastikan bahwa semua bagian sudah diuji(Feridi, 2016). Hal ini dilakukan untuk meminimalisir kesalahan (error) dan memastikan keluaran yang dihasilkan sesuai dengan yang diinginkan.

\section{Hasil dan Pembahasan}

\subsection{Flowchart Sistem}

Adapun usulan prosedur dalam sistem penjualan kredit adalah sebagai berikut:

a. Pelanggan

1) Pelanggan meminta permintaan harga ke bagian penjualan.

2) Pelanggan menerima Surat Penawaran Harga $(\mathrm{PH})$ dari bagian penjualan.

3) Membuat PO (Purchase Order) dua rangkap yang akan dikirimkan kepada bagian penjualan.

4) Menerima invoice, faktur pajak, dan Surat Jalan (SJ) rangkap satu dan dua yang sudah ditandatangani oleh pimpinan dari bagian gudang dan pengiriman.

b. Bagian Penjualan

1) Bagian penjualan menerima permintaan harga dari pelanggan dan mencetak Penawaran Harga $\mathrm{PH})$ dengan mengambil data dari entry database barang.

2) Menerima PO (Purchase Order) rangkap satu dan dua dari pelanggan. Lembar pertama akan dikirimkan ke bagian keuangan kemudian untuk lembar kedua akan diarsip berdasarkan tanggal.

3) Menginput data pelanggan dan data penjualan ke database.

c. Bagian Gudang dan Pengiriman

1) Menerima invoice, dan faktur pajak yang sudah ditandatangani oleh pimpinan dari bagian keuangan.

2) Bagian gudang mencetak Surat Jalan (SJ) sebanyak dua rangkap dengan mengentry data dari database penjualan.

3) Mengirimkan Surat Jalan (SJ) rangkap satu dan dua, invoice, faktur pajak, beserta barang ke pelanggan.

d. Bagian Keuangan

1) Menerima $P O$ (Purchase Order) Lembar pertama dari bgaian penjualan.

2) Bagian Keuangan mencetak Invoice, dan faktur pajak dengan mengentry dari database penjualan. Dan dikirimkan ke pimpinan untuk ditandatangani.

3) Mencetak laporan penjualan dan laporan piutang dengan mengentry data dari database penjualan, yang akan dikirimkan ke pimpinan.

e. Pimpinan

1) Menadatangani Invoice dan faktur Pajak.

2) Menerima laporan penjualan dan piutang dari bagian keuangan.

Adapun Flowchart sistem usulan penjualan secara kredit pada CV Ace Jaya Abadi adalah sebagai berikut: 


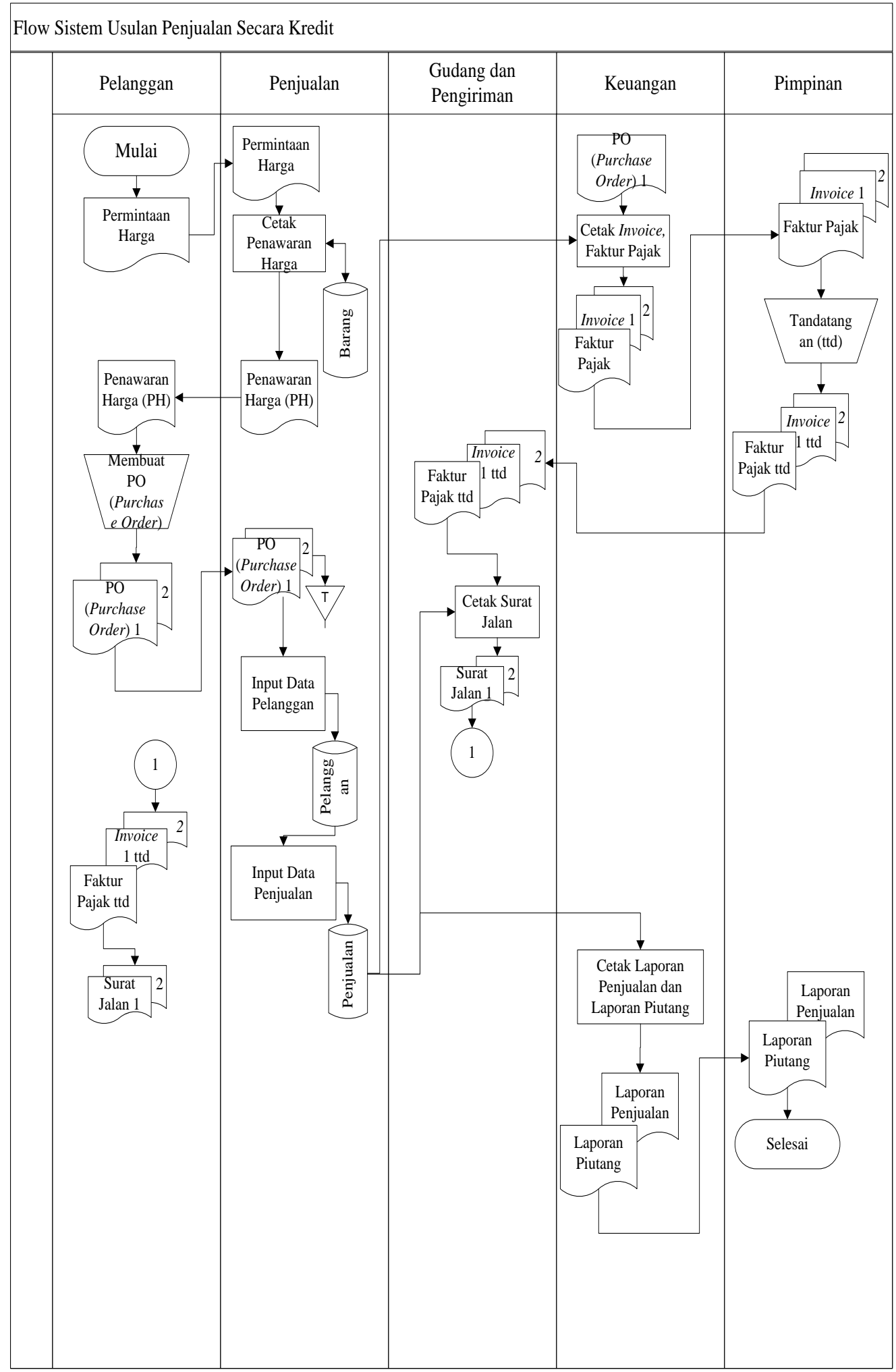

\section{Gambar 2. Flow Sistem}

Diagram Konteks (Context diagram) adalah diagram yang menggambarkan kondisi sistem yang ada baik input maupun output(A. M. Yusuf, Hasmizal, \& Dini, 2021).
Adapun gambaran Context Diagram dari penjualan kredit pada CV Ace Jaya Abadi dapat dilihat pada gambar di bawah: 


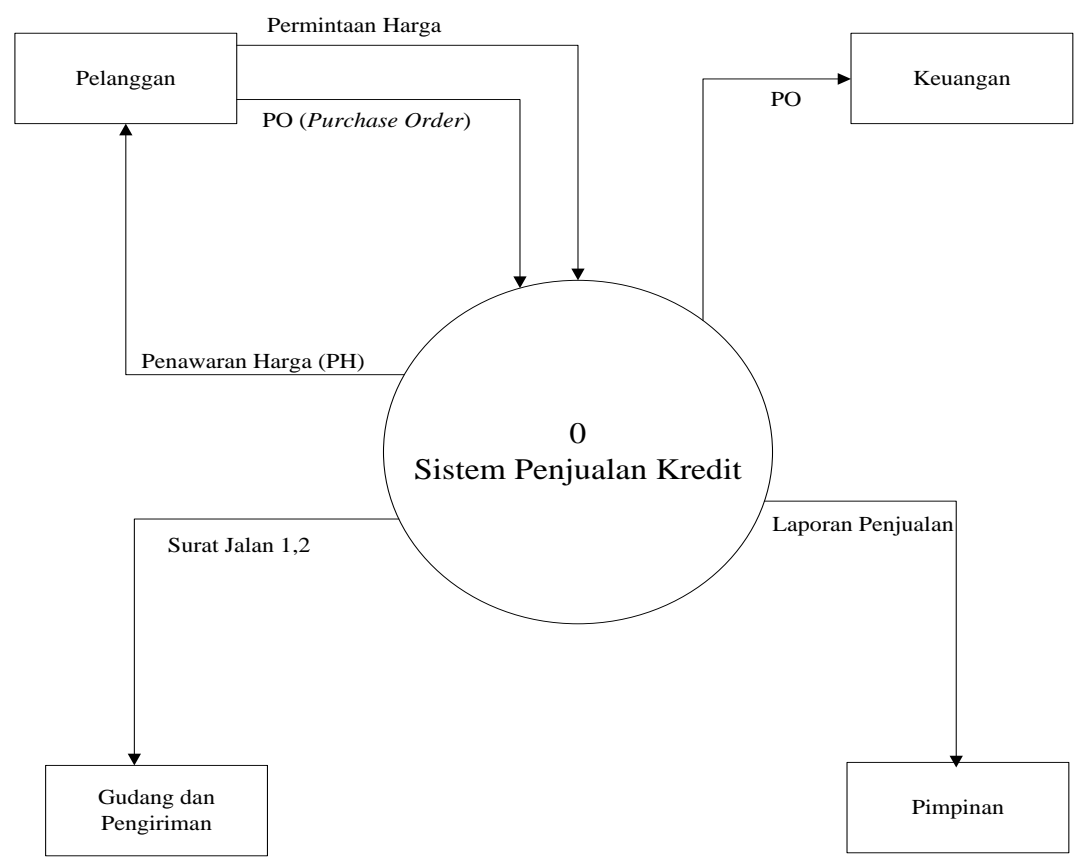

Gambar 3. Diagram Kontek

Diagram Overview akan dijelaskan proses-proses yang terjadi dalam sistem, yaitu proses cetak harga, proses input penjualan, proses cetak SP (Surat
Pengiriman), proses cetak PO (Purchase Order), proses cetak invoice, dan proses cetak laporan.

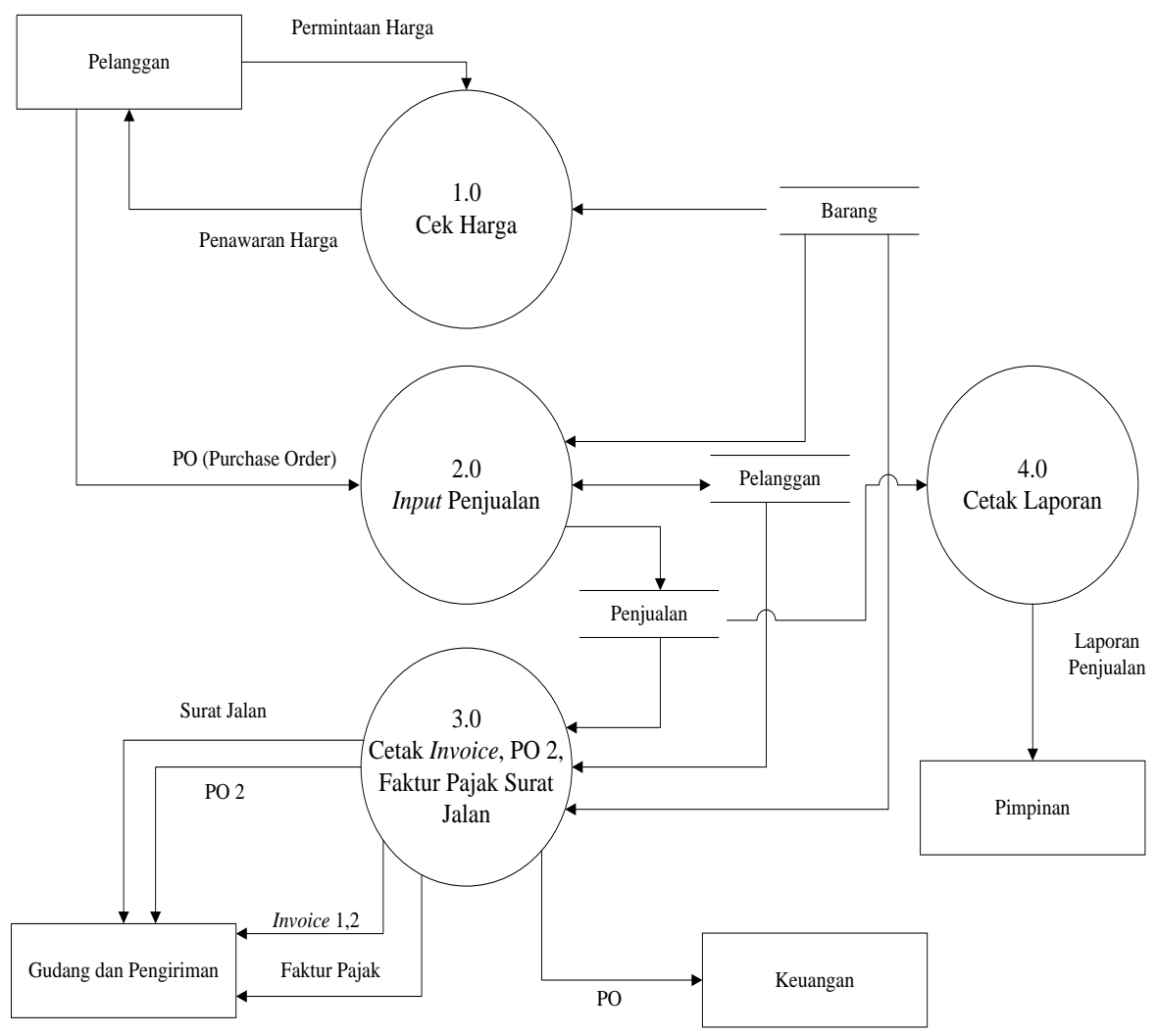

Gambar 4. Diagram Overview 


\subsection{Implementasi Sistem}

Implementasi sistem merupakan suatu proses untuk menempatkan dan menerapkan sistem informasi baru kedalam operasi sistem aplikasi. Atau bisa juga diartikan sebagai suatu proses untuk sistem informasi baru ke dalam sistem yang sudah ada (sistem lama).

a. Form Star Up

Pada layar "Star Up" merupakan layar pembuka atau ucapan selamat datang apabila saat membuka aplikasi tersebut.

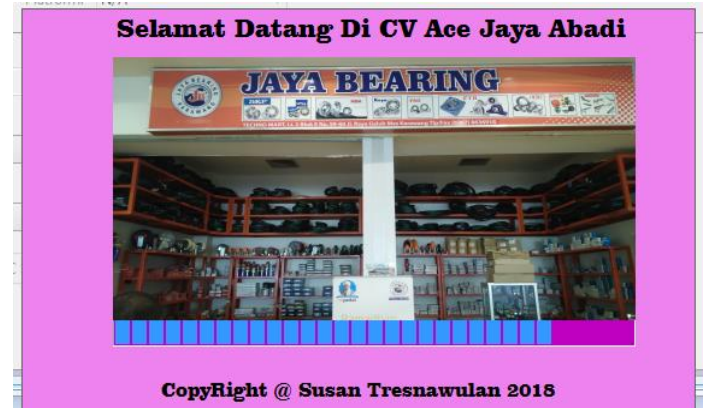

Gambar 5. Form Star Up

b. Form Login

Pada layar "Login" user memasukan nama dan password. Apabila nama atau password tidak benar, maka pada saat memilih Login tidak dapat login ke program tersebut. Tetapi apabila nama dan password yang dimasukan secara benar, maka pada saat memilih Login akan muncul Layar Menu Utama. Dan ketika memilih X (Cancel), maka akan menutup layar login.

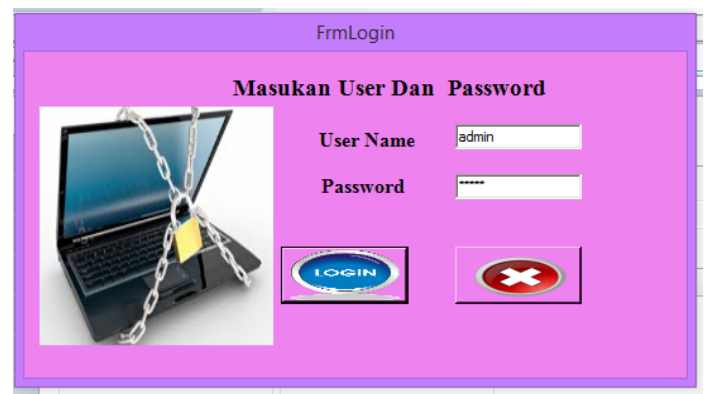

Gambar 6. Form Login

c. Form Menu Utama

Setelah user melakukan Login, maka muncul tampilan layar utama yang terdiri dari File, Master, Transaksi, dan Laporan. Jika akan memproses data, maka pilih sesuai dengan pilihan yang dibutuhkan oleh user dari tampilan layar menu utama ini.

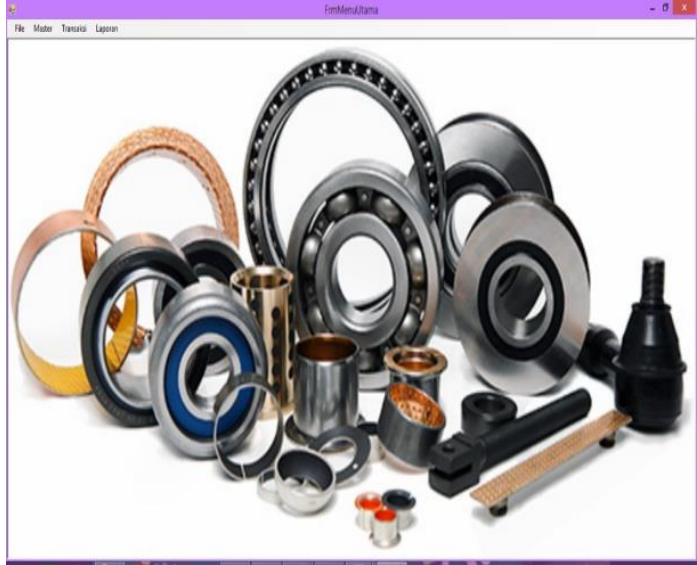

Gambar 7. Form Menu Utama

d. Form Data Barang

Form Barang digunakan untuk input data barang yang akan diperjual belikan atau bisa untuk dikredit pada $\mathrm{Cv}$ Ace Jaya Abadi. Pada layar barang, user data barang yang akan diinput harus memulai dengan baru sebagai data barang baru yang akan diinput. Apabila user sudah memasukan data barang dengan lengkap tersebut, maka pilih simpan untuk menyimpan, hapus untuk menghapus data apabila ada kesalahan input data barang tersebut dan keluar untuk keluar dari layar data barang.

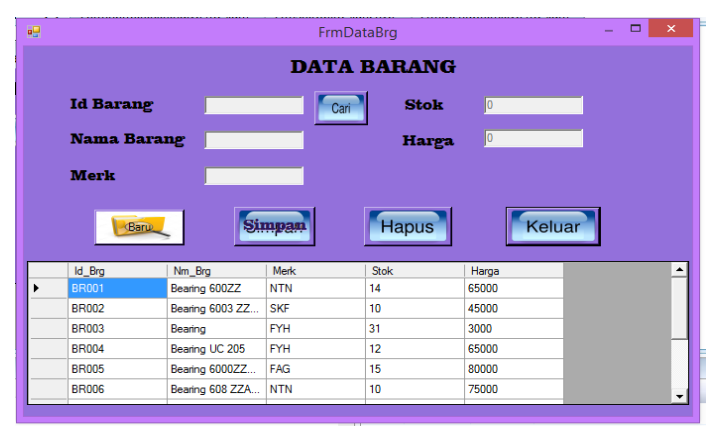

Gambar 8. Form Data Barang

e. Form Penjualan

Form Penjualan digunakan untuk input data transaksi penjualan baik secara cash maupun secara kredit. Pilih button baru untuk transaksi penjualan baru, jika menginput transaksi penjualan secara kredit ketika data transaksi di simpan maka data transaksi penjualan secara otomatis akan masuk ke laporan penjualan. 


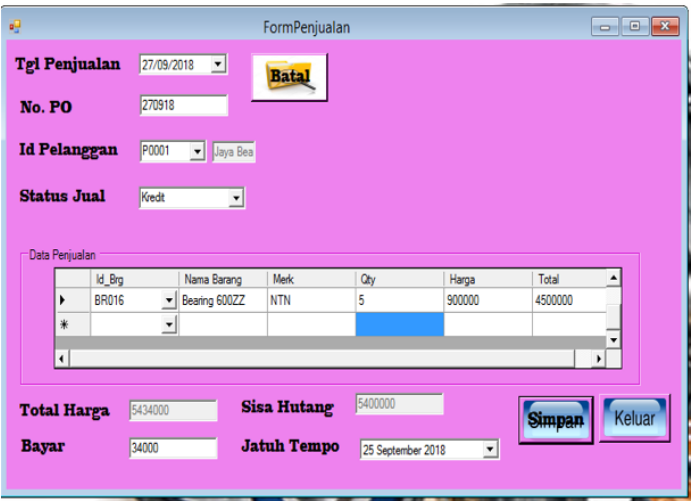

Gambar 9. Form Penjualan

f. Form Surat Jalan

Form surat jalan digunakan untuk menginput data barang yang akan dikirim ke pelanggan.

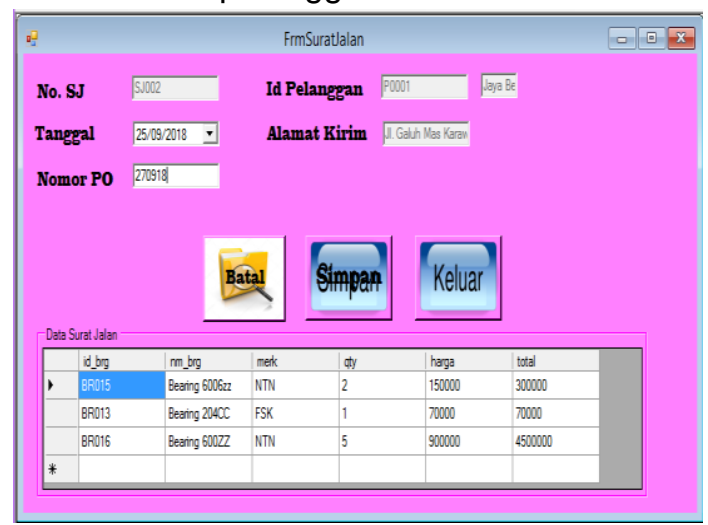

Gambar 10. Form Surat Jalan

g. Form Pembayaran

Form pembayaran digunakan untuk menginput data pembayaran kredit dari pelanggan.

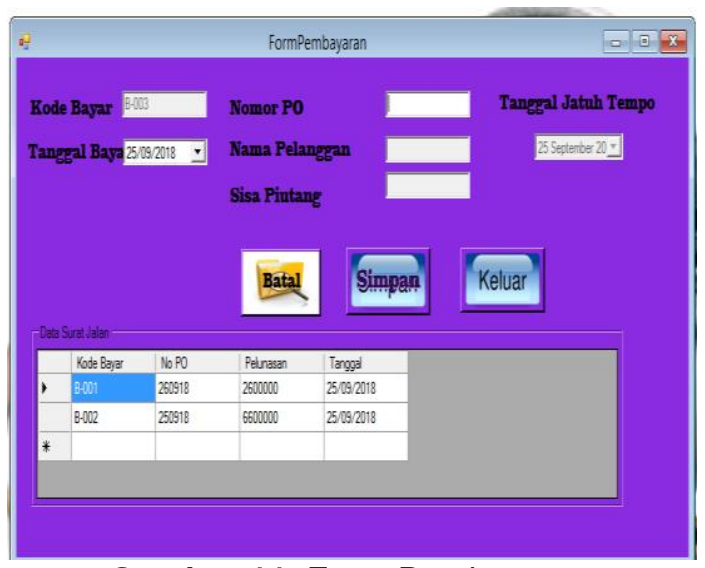

Gambar 11. Form Pembayaran

\subsection{Pengujian Sistem}

Berikut ini adalah hasil pengujian aplikasi penjualan kredit barang menggunakan metode Black Box.

Tabel 1. Black Box Testing

\begin{tabular}{|c|c|c|c|c|}
\hline No & $\begin{array}{l}\text { Fungsi yang } \\
\text { diuji }\end{array}$ & Cara pengujian & Hasil yang diharapkan & $\begin{array}{l}\text { Hasil } \\
\text { Pengujian }\end{array}$ \\
\hline 1. & Form Star Up & $\begin{array}{l}\text { Pada form ini tampilan } \\
\text { pembukaan awal untuk } \\
\text { aplikasi. }\end{array}$ & $\begin{array}{l}\text { Menampilkan halaman } \\
\text { pembuka di dalam aplikasi. }\end{array}$ & OK \\
\hline 2. & Form Login & $\begin{array}{l}\text { form Login digunakan } \\
\text { sebagai awal masuk ke } \\
\text { dalam sistem dengan } \\
\text { memasukan username } \\
\text { dan password. }\end{array}$ & $\begin{array}{l}\text { Menampilkan halaman } \\
\text { login dan berhasil masuk } \\
\text { ke dalam aplikasi sebagai } \\
\text { admin. }\end{array}$ & OK \\
\hline 3. & $\begin{array}{l}\text { Form Menu } \\
\text { Utama }\end{array}$ & $\begin{array}{l}\text { Setelah berhasil masuk, } \\
\text { menampilkan halaman } \\
\text { menu utama. }\end{array}$ & $\begin{array}{l}\text { Menampilkan halaman } \\
\text { menu utama. }\end{array}$ & OK \\
\hline 4. & $\begin{array}{l}\text { Form Data } \\
\text { Barang }\end{array}$ & $\begin{array}{l}\text { Memilih toolbar Data } \\
\text { Barang. }\end{array}$ & $\begin{array}{l}\text { Menampilkan Form Data } \\
\text { Barang, mengisi, mengedit, } \\
\text { dan menghapus data } \\
\text { barang. }\end{array}$ & OK \\
\hline 5. & $\begin{array}{l}\text { Form } \\
\text { Penjualan }\end{array}$ & $\begin{array}{l}\text { Memilih } \\
\text { Penjualan }\end{array}$ & $\begin{array}{l}\text { Menampilkan form } \\
\text { penjualan, mengisi, } \\
\text { menyimpan, mencari data } \\
\text { dan menghapus data } \\
\text { penjualan. }\end{array}$ & OK \\
\hline 6. & $\begin{array}{l}\text { Form Surat } \\
\text { Jalan }\end{array}$ & $\begin{array}{l}\text { Memilih toolbar Surat } \\
\text { Jalan }\end{array}$ & $\begin{array}{l}\text { Menampilkan form surat } \\
\text { jalan, dengan mengisi, } \\
\text { menyimpan, menghapus }\end{array}$ & OK \\
\hline
\end{tabular}




\begin{tabular}{|c|c|c|c|c|}
\hline & & & data surat jalan. & \\
\hline 7. & $\begin{array}{l}\text { Form } \\
\text { Pembayaran }\end{array}$ & $\begin{array}{ll}\text { Memilih } & \text { toolbar } \\
\text { Pembayaran. } & \end{array}$ & $\begin{array}{lr}\text { Menampilkan } & \text { Form } \\
\text { pembayaran kredit pada } \\
\text { transaksi } & \text { penjualan, } \\
\text { dengan cara mengisi, } \\
\text { menyimpan }\end{array}$ & $\mathrm{OK}$ \\
\hline
\end{tabular}

\section{Kesimpulan}

Berdasarkan hasil penelitian dan pengamatan yang penulis lakukan di CV Ace Jaya Abadi terhadap sistem yang berjalan menghasilkan kesimpulan yaitu pengolahan data terhadap pembuatan laporan penjualan kredit maupun penangan order yang lebih mudah, CV Ace Jaya Abadi sudah menyediakan sistem yang berbasis komputerisasi yang menggunakan bahasa pemrograman yang didalamnya mencakup database dan sistem dapat berjalan dengan baik yang didukung dengan pengetahuan dan kemampuan yang cukup dari setiap user yang mengoperasikan karena telah mengikuti pelatihan.

\section{Referensi}

Arsyad, O. R., Kurnia, \& Kartika, P. (2021). Pengertian Observasi. Rancang Bangun Alat Pengaman Brankas Menggunakan Sensor Sidik Jari Berbasis Arduino.

Bastian, I., Winardi, R. D., \& Fatmawati, D. (2018). Metoda Wawancara. Metoda Pengumpulan Dan Teknik Analisis Data.

Febrianto, C. (2020). Desain Perangkat Lunak. Blogspot.Com.

Feridi. (2016). Pentingnya Pengujian Perangkat Lunak. Codepolitan.

Hendrawan, M. R. (2019). Analisis Kualitas Perangkat Lunak Senayan Library Management System Versi 8 Akasia sebagai Sistem Otomasi Perpustakaan. Lentera Pustaka: Jurnal Kajian Ilmu Perpustakaan, Informasi Dan Kearsipan. https://doi.org/10.14710/lenpust.v4i2.2 1266

Permana, A. Y., \& Romadlon, P. (2019). PERANCANGAN SISTEM INFORMASI PENJUALAN PERUMAHAN MENGUNAKAN METODE SDLC PADA PT. MANDIRI LAND PROSPEROUS BERBASIS MOBILE. SIGMA - Jurnal Teknologi Pelita Bangsa.
Rosa A.S, M. S. (2016). Model Waterfall. 2016. Bandung: Informatika.Model Waterfall. 2016.

Sadiah, J., Indaryono, I., \& Yusuf, A. M. (2021). Sistem Informasi Akuntansi Penggajian Berbasis Vb.Net Pada PT BANK PERKREDITAN RAKYAT (BPR) SANGGABUANA AGUNG KARAWANG. Jurnal Interkom: Jurnal Publikasi IImiah Bidang Teknologi Informasi Dan Komunikasi. https://doi.org/10.35969/interkom.v15i4 .80

Sitorus, M. C., \& Kurniawan, A. (2021). Pengaruh Penjualan Tunai Dan Penjualan Kredit Terhadap Profitabilitas Perusahaan Pada PD Gloria Bandung. Jurnal Financia.

Sugiyono, universitas negeri. (2019). Studi pustaka. Journal of Chemical Information and Modeling.

Yusuf, A. M., Hasmizal, H., \& Dini, N. (2021). Sistem Informasi Perhitungan Penyusutan Aktiva Tetap Menggunakan Metode Garis Lurus Berbasis Vb.Net Pada CV Ginanjar Sejahtera Mandiri Karawang. Jurnal Interkom: Jurnal Publikasi IImiah Bidang Teknologi Informasi Dan Komunikasi.

https://doi.org/10.35969/interkom.v16i1 .95

Yusuf, M. (2019). Pengaruh Kemajuan Teknologi dan Pengetahuan terhadap Minat Generasi Milenial dalam Berinvestasi di Pasar Modal. JURNAL DINAMIKA MANAJEMEN DAN BISNIS.

https://doi.org/10.21009/jdmb.02.2.3 